Crop Breeding and Applied Biotechnology 13: 165-171 2013

Brazilian Society of Plant Breeding. Printed in Brazil

\title{
ARTICLE
}

\section{The effect of growth regulators on sex expression in melon (Cucumis melo L.)}

Zdenka Girek ${ }^{1}$, Slaven Prodanovic ${ }^{2}$, Jasmina Zdravkovic ${ }^{1}$, Tomislav Zivanovic ${ }^{2}$, Milan Ugrinovic $^{1}$ and Milan Zdravkovic $^{1}$

Received 19 August 2012

Accepted 06 September 2013

\begin{abstract}
Seven traits related to flowering and sex expression in melon were studied and their reaction to application of two growth regulators (ethrel and gibberellic acid) was observed. Four monoecious genotypes (Sesame, ED-3, ED-4, Pobeditel) and four andromonoecious genotypes (Chinese muskmelon, Anannas, Fiata, A2-3lb) had been used for experiments. According to the results, ethrel had higher effects on the investigated traits than gibberellic acid. Ethrel increased the number of perfect flowers per plant for $7.18(31.42 \%)$, reduced the number of male flowers per plant for 21.47 (17.98\%), affected earlier appearance of the first pistillatel perfect flower for 3.68 days, and delayed the appearance of the first staminate flower for 16.07 days. Changes in the last two traits caused an extension of the period from the emergence of the first pistillate/perfect to the first staminate flower from 0.1 to 21.57 days, which represents the strongest effect of ethrel. Gibberellic acid had generally opposite effects on the studied traits.
\end{abstract}

Key words: Andromonoecious, ethrel, flower, gibberellic acid, monoecious.

\section{INTRODUCTION}

Melon (Cucumis melo L.) is an economically important annual species cultivated all over the world. It belongs to the family Cucurbitaceae, genus Cucumis. Melon world harvested area is about one million hectars and its production is about 25 million tons (FAO 2010).

Melon flower biology and sexual expression are important traits for breeding programs. Melon commercial cultivars belong mostly to the andromonoecious sex type (bisexual (perfect) flowers and male, or staminate flowers, in the same plant) and partly to the monoecious sex type (male or staminate and female, or pistillate flowers, in the same plant) (Wang et al. 2007, Abdelmohsin and Pitrat 2008). Two major genes are involved in genetic control of sex expression in melon: allele $a$ controls presence/absence of pistil in female flowers, and allele $g$ controls presence/ absence of two types of flowers in the same plant (Pitrat 2008, Martin et al. 2009). Different allele combinations of these two genes result in four distinct genotypes: hermaphrodite (aagg), gynoecious ( $A A g g)$, monoecious $\left(A \_G \_\right.$) and andromonoecious $\left(a a G_{-}\right)$.

Sex expression in melon can be modified by external factors, such as mineral nutrition, temperature, water regime, light intensity, photoperiod, mechanical trauma and application of growth regulators (Whitaker 1931, Brantley and Warren 1960, Freeman et al. 1980). Growth regulators or phytohormones, especially ethylene / ethrel (Papadopoulou et al. 2005, Manzano et al. 2008) and gibberellic acid, i.e.GA 3 (Thomas 2008), are mostly used to modify sex expression in melon.

Several investigations have shown that phytohormones are involved in changes of flower type, number and ratio of flowers of different sex types, modifications of flowering time and of other traits related to sex expression (Noguera et al. 2005, Papadopoulou et al. 2005, Stankovic et al. 2005, Yamasaki et al. 2005, Little et al. 2007, Boualem et al. 2008, Ouzounidou et al. 2008, Boualem et al. 2009, Martin et al. 2009). Most of these studies were performed in cucumber, the model plant for studying sex expression in Cucurbitaceae. Also, most of these investigations were focused only on one or few traits and by using a specific phytohormone.

However, it is known that phytohormones could have opposite effects on sex expression (Yin and Quinn 1995).

\footnotetext{
${ }^{1}$ Institute for Vegetable Crops, Karadjordjeva 71, 11420, Smederevska Palanka, Serbia

${ }^{2}$ University of Belgrade, Faculty of Agriculture, Nemanjina 6, 11080, Zemun, Belgrade, Serbia
} 
The aim of this research was to study the effect of different phytohormones on the traits related to sex expression (type of flowers according to sex, ratio between different flower types, time and dynamic of flowering, fruit number and time of ripening) in melon. For the first time, the effect of ethrel and gibberellic acid on the interval between emergence of the first staminate flower and the first perfect/ pistillate flower per plant was studied on monoecious and andromonoecious melon cultivars.

\section{MATERIAL AND METHODS}

Eight melon genotypes belonging to different sex types and carrying different flower types (Figure 1) were used as material in this study: four monoecious (Sesame, from Serbia; Early dawn 3 (ED-3) and Early dawn 4 (ED-4), from USA; Pobeditel, from Bulgaria) and four andromonoecious (Chinese muskmelon, from China; Anannas, from Serbia; Fiata, from Netherland; A2-3lb, from Austria).

Melon seeds were sown in clay pots $(10 \mathrm{~cm}$ in diameter) in greenhouse, in the first week of April and treated three times with ethrel (2-chloroethyl phosphoric acid) and gibberellic

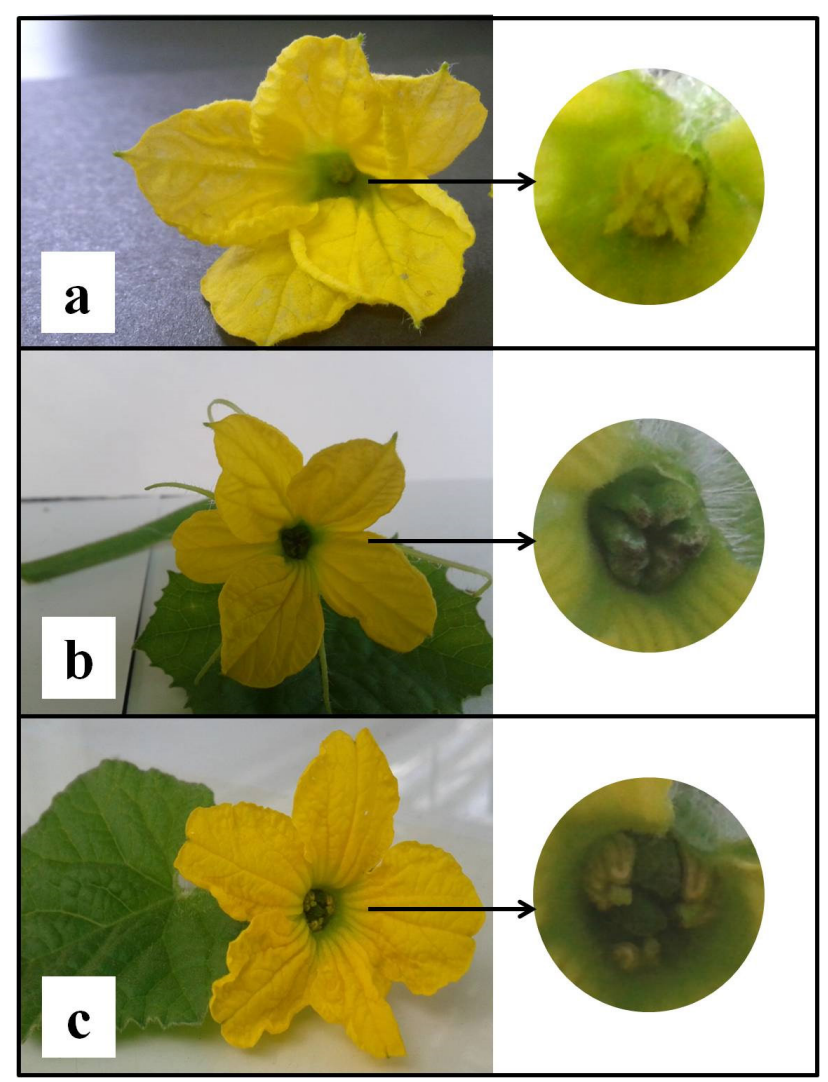

Figure 1. Flower types in melon: (a) staminate flower (with only male reproductive organs - stamens), (b) pistillate flower (with only female reproductive organs - pistil), (c) perfect flower (with male and female reproductive organs - stamens and pistil). acid $\left(\mathrm{C}_{19} \mathrm{H}_{22} \mathrm{O}_{6}\right)$ during the development period: at the stage of 3-5 leaves; five days later the stage of 3-5 leaves, and 10 days later the stage 3-5 leaves. In previous researches it was found that, the largest effects on the modification of sex expression in melon have ethrel $(0.024 \%)$ and GA3 (0.2\%). There were 90 plants within each genotype, of which 30 plants were not treated with phytohormones; therefore, they were used as controls in the field experiments.

Plants were transferred to the field in the phase of 7-9 leaves. Field experiments were set up during two growing seasons (2010 and 2011) at the experimental field of the Institute for Vegetable Crops in Smederevska Palanka, Serbia (lat $44^{\circ} 21^{\prime} 22.46^{\prime \prime} \mathrm{N}$, long $20^{\circ} 57^{\prime} 08.97^{\prime \prime} \mathrm{E}$, and alt $101 \mathrm{~m}$ asl). The soil type at this location was vertisol (Aydinalp 2010).

The field experiments were done in three replications using complete randomized block design of 8 plots in one block (one plot for each genotype). Each plot consisted of 3 rows (ethrel, $\mathrm{GA}_{3}$ and control) with a $150 \mathrm{~cm}$ distance between rows, and 10 plants per row with a $100 \mathrm{~cm}$ distance between plants.

The following characteristics were measured: number of pistillate/perfect flowers per plant, number of staminate flowers per plant, number of fruits per plant, period from sowing to the emergence of the first perfect/pistillate flower (in days), period from sowing to the emergence of the first staminate flower (in days), period from sowing to full fruit ripening (in days), and period from the emergence of the first staminate to the emergence of the first perfect/pistillate flower per plant (in days).

The results were statistically analyzed, using ANOVA and the Fisher's Least Significant Difference $(L S D)$ test (Fisher 1935).

\section{RESULTS AND DISCUSSION}

Mean values for seven characteristics related to sex expression in untreated melon plants (control) are presented in Table 1. According to the results, the number of pistillate flowers developed in the monoecious genotypes (14.82) was about two times lower than the number of perfect flowers developed in andromonoecious plant (22.85). Number of staminate flowers per plant was about $15 \%$ lower in monoecious genotypes (110.28) than in andromonoecious genotypes (128.53). The number of fruit per plant was lower in monoecious genotypes (1.38) than in andromonoecious genotypes (1.86). The highest number of perfect flowers (28.06), staminate flowers (142.22) and fruits (2.85) was observed in A2-3lb genotype. There was no significant difference between the two types of melon genotypes (monoecious and andromonoecious) regarding the period 
from sowing to the emergence of the first perfect/pistillate flower, period from sowing to the emergence of the first staminate flower, and period from sowing to full fruit ripening. Time from the emergence of the first staminate to the emergence of the first pistillate/perfect flower varied more in monoecious genotypes (from 10.17 in Sesame to 26.06 in Pobeditel) then in andromonoecious genotypes (from 20.33 in Anannas to 22.06 in Fiata).

Tables 2 and 3 present the effect of ethrel, while Table 4 and 5 present the effect of $\mathrm{GA}_{3}$ in each of these traits, comparing treated versus control plants. Ethrel treatment induced a higher number of pistillate flowers in monoecious plants than in the control and the stronger effect was observed in Pobeditel genotype (Table 3). The average number of pistillate flowers in Pobeditel plants sprayed with ethrel was increased by 13.44 flowers, compared to the control. Ethrel also had effect on the number of perfect flowers per plant in andromonoecious genotypes. Andromonoecious plants sprayed with ethrel had a higher number of perfect flowers, comparing to the control (Table 3 ). The average number of perfect flowers in andromonoecious plants after ethrel treatment was higher in comparison to the average number of pistillate flowers developed at monoecious plants sprayed with the same plant growth regulator (Table 2). However, compared to control group of plants, a stronger effect of treatment was observed in monoecious plants (Table 3).

Gibberellic acid reduced the number of pistillate flowers per plant in three monoecious genotypes, but it presented the opposite effect on the cultivar Pobeditel. The average number of pistillate flowers in this cultivar was higher by

Table 1. Traits of melon cultivars untreated with growth regulators (control)

\begin{tabular}{|c|c|c|c|c|c|c|c|}
\hline \multirow[b]{2}{*}{ Cultivar } & \multirow[b]{2}{*}{$\begin{array}{l}\text { Number of } \mathbf{P i}^{1} / \mathbf{P r}^{2} \\
\text { flowers per plant }\end{array}$} & \multirow{2}{*}{$\begin{array}{l}\text { Number of } \mathrm{St}^{3} \\
\text { flowers per } \\
\text { plant }\end{array}$} & \multirow{2}{*}{$\begin{array}{l}\text { Number of } \\
\text { fruits per } \\
\text { plant }\end{array}$} & \multicolumn{3}{|c|}{ Period from sowing } & \multirow{2}{*}{$\begin{array}{l}\text { From first } \mathrm{St}^{3}{ }^{3} \\
\text { to first } \mathbf{P i}^{1} / \mathbf{P r}^{2} \\
\text { flower }\left(\mathbf{d}^{4}\right)\end{array}$} \\
\hline & & & & $\begin{array}{l}\text { To first } \mathbf{P i}^{1 /} / \mathbf{P r}^{2} \\
\text { flower }\left(\mathrm{d}^{4}\right)\end{array}$ & $\begin{array}{l}\text { To first } \mathbf{S t}^{3} \\
\text { flower }\left(\mathbf{d}^{4}\right)\end{array}$ & $\begin{array}{l}\text { To full fruit } \\
\text { ripening }\left(d^{4}\right)\end{array}$ & \\
\hline Sesame & 20.89 & 114.50 & 1.75 & 66.61 & 56.44 & 104.94 & 10.17 \\
\hline ED-4 & 13.39 & 110.11 & 1.45 & 75.83 & 57.67 & 116.72 & 18.17 \\
\hline Pobeditel & 12.67 & 109.89 & 1.30 & 76.50 & 50.44 & 115.28 & 26.06 \\
\hline Anannas & 14.00 & 113.56 & 0.85 & 71.39 & 51.06 & 113.11 & 20.33 \\
\hline Fiata & 23.67 & 131.61 & 1.70 & 71.06 & 49.00 & 114.39 & 22.06 \\
\hline A2-3lb & 28.06 & 142.22 & 2.85 & 74.11 & 53.67 & 114.44 & 20.44 \\
\hline $\mathrm{M}\left(\mathrm{Am}^{6}\right)$ & 22.85 & 128.53 & 1.86 & 73.49 & 52.34 & 115.07 & 21.15 \\
\hline
\end{tabular}

${ }^{1} \mathrm{Pi}$ - pistillate; ${ }^{2} \mathrm{Pr}$ - perfect; ${ }^{3} \mathrm{St}$ - staminate; ${ }^{4} \mathrm{~d}$ - days; ${ }^{\mathrm{M}} \mathrm{Mo}$ - monoecious; ${ }^{6} \mathrm{Am}$ - andromonoecious

Table 2. Characteristics of melon cultivars treated with ethrel

\begin{tabular}{|c|c|c|c|c|c|c|c|}
\hline \multirow[b]{2}{*}{ Cultivar } & \multirow{2}{*}{$\begin{array}{l}\text { Number of } \mathrm{Pi}^{1 /} \\
\mathrm{Pr}^{2} \text { flowers per } \\
\text { plant }\end{array}$} & \multirow{2}{*}{$\begin{array}{l}\text { Number of } \mathrm{St}^{3} \\
\text { flowers per } \\
\text { plant }\end{array}$} & \multirow{2}{*}{$\begin{array}{l}\text { Number of } \\
\text { fruits per } \\
\text { plant }\end{array}$} & \multicolumn{3}{|c|}{ Period from sowing } & \multirow{2}{*}{$\begin{array}{l}\text { From first } \mathrm{St}^{3} \\
\text { to first } \mathbf{P i}^{1} / \mathbf{P r}^{2} \\
\text { flower }\left(\mathbf{d}^{4}\right)\end{array}$} \\
\hline & & & & $\begin{array}{l}\text { To first } \mathrm{Pi}^{1} / \mathbf{P r}^{2} \\
\text { flower }\left(\mathrm{d}^{4}\right)\end{array}$ & $\begin{array}{l}\text { To first } S^{3} \\
\text { flower }\left(d^{4}\right)\end{array}$ & $\begin{array}{l}\text { To full fruit } \\
\text { ripening }\left(d^{4}\right)\end{array}$ & \\
\hline Sesame & 28.39 & 93.89 & 1.35 & 65.11 & 67.17 & 103.72 & -2.06 \\
\hline ED-4 & 19.72 & 82.22 & 1.25 & 70.22 & 69.50 & 108.17 & 0.72 \\
\hline Pobeditel & 26.11 & 94.33 & 1.05 & 69.39 & 68.72 & 113.17 & 0.67 \\
\hline $\mathrm{M}\left(\mathrm{Mo}^{5}\right)$ & 22.94 & 87.56 & 1.04 & 69.26 & 69.06 & 108.49 & 0.21 \\
\hline Anannas & 25.44 & 91.44 & 1.05 & 73.22 & 73.11 & 110.56 & 0.11 \\
\hline Fiata & 29.17 & 111.94 & 1.90 & 69.39 & 69.56 & 107.72 & -0.17 \\
\hline A2-3lb & 34.06 & 124.89 & 1.55 & 71.11 & 70.83 & 110.28 & 0.28 \\
\hline $\mathrm{M}\left(\mathrm{Am}^{6}\right)$ & 30.03 & 108.30 & 1.54 & 71.07 & 71.48 & 110.61 & -0.42 \\
\hline M (Total) & 26.49 & 97.93 & 1.29 & 70.16 & 70.27 & 109.55 & -0.10 \\
\hline
\end{tabular}

${ }^{1} \mathrm{Pi}$ - pistillate; ${ }^{2} \mathrm{Pr}$ - perfect; ${ }^{3} \mathrm{St}$ - staminate; ${ }^{4} \mathrm{~d}$ - days; ${ }^{\mathrm{M}} \mathrm{Mo}$ - monoecious; ${ }^{6} \mathrm{Am}$ - andromonoecious 
3.11 flowers, or $24.54 \%$, comparing to control (Table 5). GA effect was more visible in the number of perfect flowers of andromonoecious plants. The strongest effect was observed at the A2-3lb genotype, in which the number of perfect flowers per plant decreased by 4.73 flowers, compared to control (Table 5).

Manzano et al. (2008) also found that ethrel promotes feminization of melon plants, but concluded that ethrel had strongest effect in gynoecious than in monoecious and andromonoecious plants, in which the effect was significantly reduced. In Momordica charantia L. (monoecious) it was also reported that spraying plants with ethrel and $\mathrm{GA}_{3}$ resulted in sex modification. Ethrel (Thomas 2008) was more effective than $\mathrm{GA}_{3}$ in terms of induction of pistillate flowers, as well as in percentage of pistillate flowers per plant. In this study, percentage of pistillate flowers in plants sprayed with ethrel was increased by $15 \%$, compared to control. Percentage of pistillate flowers in plants treated with $\mathrm{GA}_{3}$ was $8 \%$ increased, compared to control.

Application of ethrel in monoecious plants reduced the number of staminate flowers per plant. Strongest effect was observed in Early dawn 4, in which the number of staminate flowers decreased for 27.89 flowers, compared to control (Table 3). The weakest effect of ethrel was recorded in cultivar Pobeditel. Here, the number of staminate flowers was decreased for 15.56 flowers, in comparison to control (Table 3). Similarly, ethrel decreased the number of staminate flowers in andromonoecious plants, compared to control.

Table 3. Effect of ethrel on melon traits related to sex expression

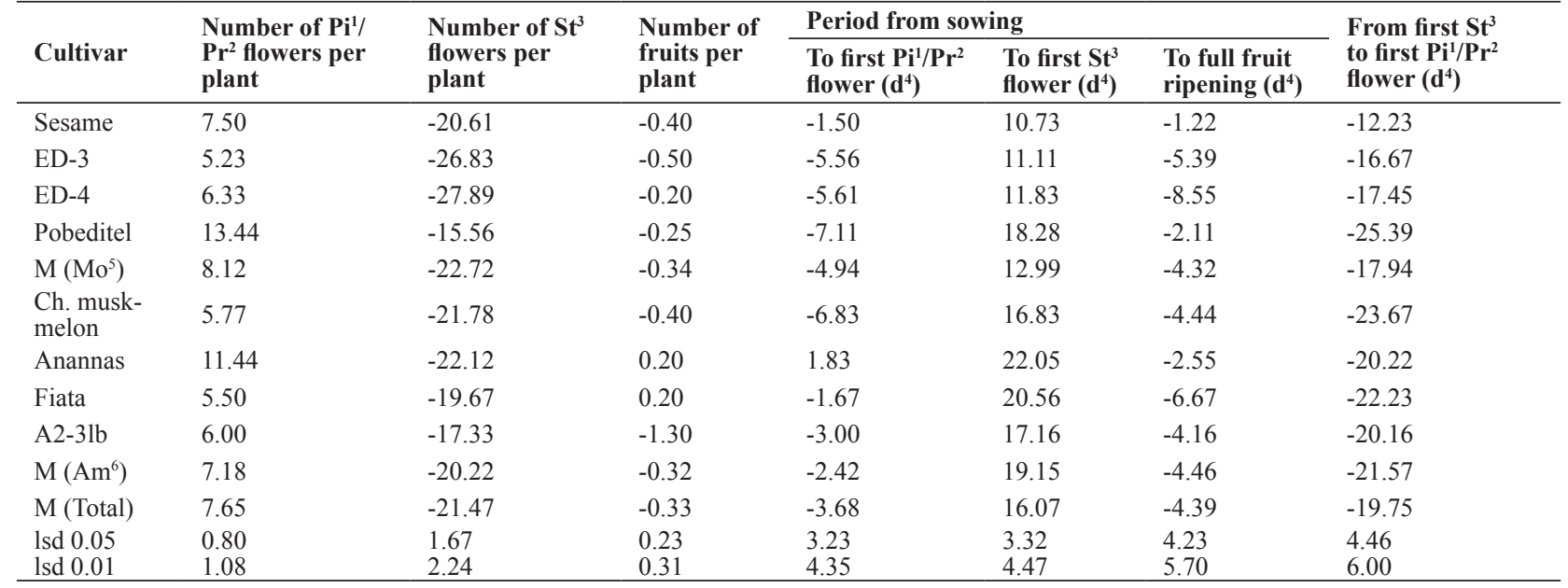

${ }^{1} \mathrm{Pi}$ - pistillate; ${ }^{2} \mathrm{Pr}$ - perfect; ${ }^{3} \mathrm{St}$ - staminate; ${ }^{4} \mathrm{~d}$ - days; ${ }^{5} \mathrm{Mo}$ - monoecious; ${ }^{6} \mathrm{Am}$ - andromonoecious

Table 4. Characteristics of melon cultivars treated with $\mathrm{GA}_{3}$

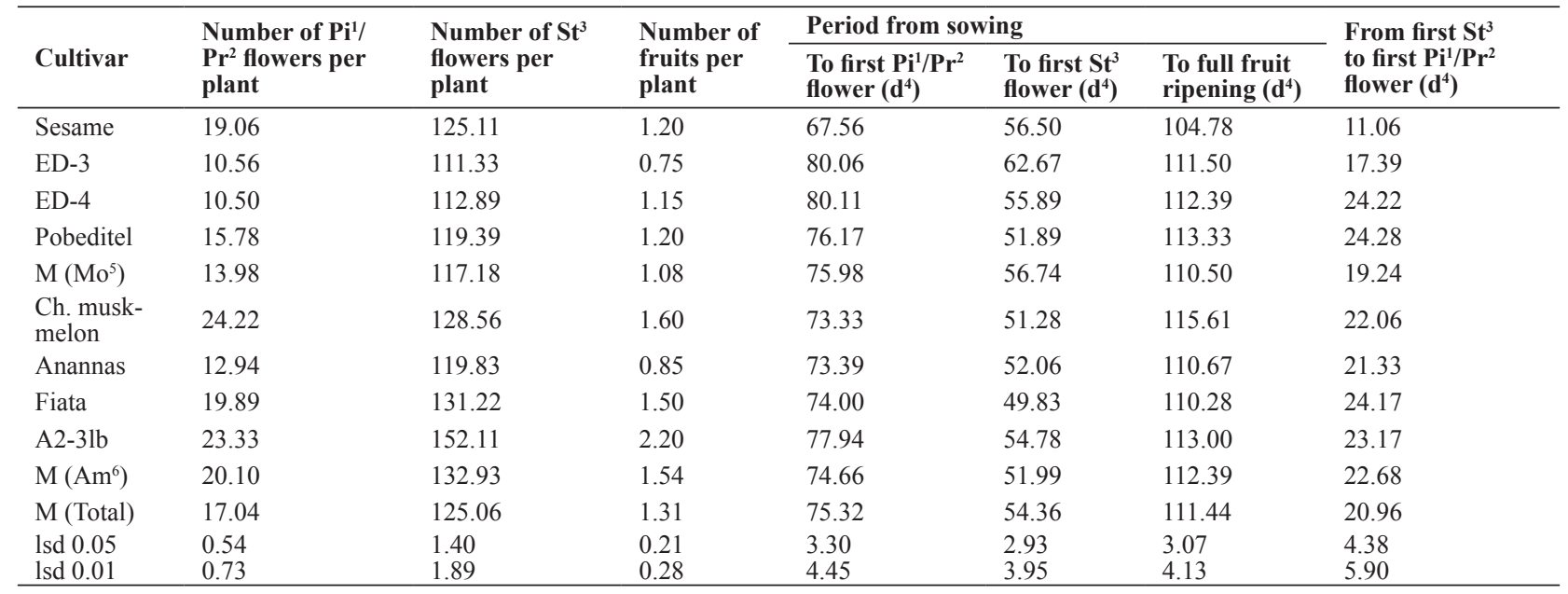

${ }^{1} \mathrm{Pi}$ - pistillate; ${ }^{2} \mathrm{Pr}$ - perfect; ${ }^{3} \mathrm{St}$ - staminate; ${ }^{4} \mathrm{~d}$ - days; ${ }^{\mathrm{M}} \mathrm{Mo}$ - monoecious; ${ }^{6} \mathrm{Am}$ - andromonoecious 
However, the stronger effect was observed in monoecious genotypes, in which the average number of male flowers (87.56; Table 2) decreased by $20.60 \%$ compared to its control (110.28; Table 1), than in andromonoecious genotypes, in which the average number of male flowers (108.30; Table 2) decreased $15.74 \%$ compared to its control (128.53; Table 1).

In monoecious plants, after application of $\mathrm{GA}_{3}$, the average number of staminate flowers per plant increased by 6.90 flowers (Table 5). GA 3 had maximum affect on early maturing Sesame cultivar, increasing the average number of male flowers per plant for 10.61 flowers. Gibberellic acid increased the number of staminate flowers per plant in all observed genotypes, except Fiata, in which a slight decrease in the number of staminate flowers per plant ( 0.39 flowers) was observed (Table 5).

Yin and Quinn (1995) tested plant growth regulators ( $\mathrm{GA}_{3}$, ethrel, $\mathrm{AgNO}_{3}, \mathrm{PCA}$ and their combinations) in monoecious and andromonoecious cucumber genotypes and concluded that any treatment promoting masculinization would produce a sex ratio quite similar to the controls. They found that after application of ethrel, monoecious and andromonoecious plants developed only female flowers. Based on their results, $\mathrm{GA}_{3}$ contributed to the decrease of staminate flowers number in monoecious plants by $16 \%$ (compared to control). In andromonoecious plants, after spraying with this plant growth regulator, number of male flowers was 58\% higher, in comparison to control.

Ripening of fruits developed on plants treated with plant growth regulators was faster than of the fruits developed in untreated plants (Tables 3 and 5). Ethrel effect was a bit stronger than $\mathrm{GA}_{3}$ effect. The application of plant growth regulators similarly affected the two groups of melon varieties regarding to the period from sowing to the full fruit ripening. The strongest effect of ethrel application was noted in Early dawn 4, in which fruits ripened 9 days earlier than fruits grown in control plants. The weakest effect was noted in Sesame, in which the fruits in treated plants ripened only one day earlier than the fruits grown in control plants (Table 3). The strongest effect of $\mathrm{GA}_{3}$ was noted in Early dawn 4, in which fruits ripened 4 days earlier than in the control, while the weakest effect also was noted in Sesame (Table 5).

In previous studies, plants treated with ethrel had fruits ripening 6-9 days earlier compared to control (Stankovic et al. 2001).

In monoecious genotypes treated with ethrel, the average number of fruits per plant ranged from 0.5 to 1.35 , and in andromonoecious genotypes it ranged from 1.05 to 1.90 (Table 2). Monoecious plants treated with gibberellic acid developed 0.75 to 1.20 fruits, and andromonoecious plants, 0.85 to 2.20 fruits (Table 4). Compared to the control, in monoecious genotypes treated with ethrel, number of fruits per plant was decreased by $24.64 \%$, and in andromonoecious genotypes, by $17.20 \%$. Ethrel had the strongest positive effect on Anannas and Fiata cultivars, in which the number of fruits per plant increased by $23.53 \%$ and 11.76 $\%$, respectively, in relation to control (Table 3). Both plant growth regulators had strongest negative effect on A2-3lb genotype, in which the number of fruits per plant decreased by $45.61 \%$ (ethrel; Table 3 ) and $22.81 \%\left(\mathrm{GA}_{3}\right.$; Table 5).

Thomas (2008) reported that in bitter melon, ethrel was more effective in the percentage of pistillate flowers which formed fruits than $\mathrm{GA}_{3}$.

The application of ethrel affects time of appearance of the first flower on plants with female reproductive organs. In monoecious plants, pistillate flowers appeared 5 days earlier

Table 5. Effect of $\mathrm{GA}_{3}$ on melon traits related to sex expression

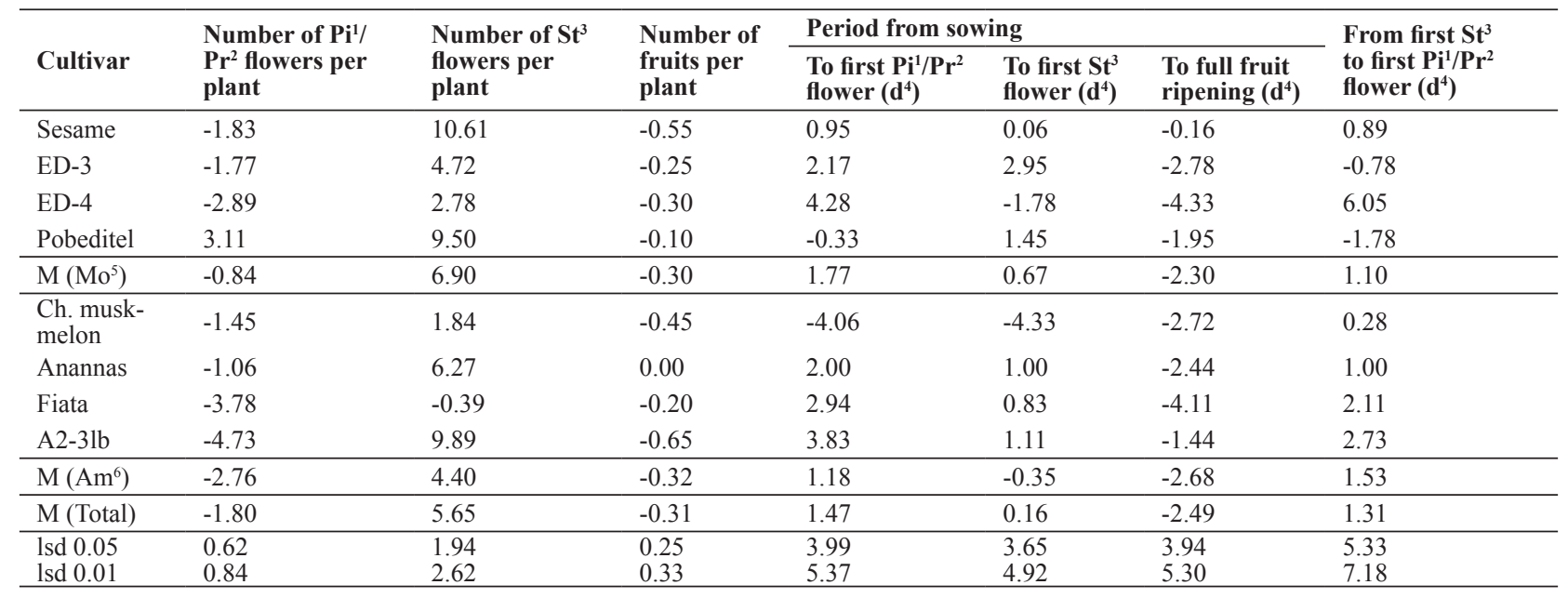

${ }^{1} \mathrm{Pi}$ - pistillate; ${ }^{2} \mathrm{Pr}$ - perfect; ${ }^{3} \mathrm{St}$ - staminate; ${ }^{4} \mathrm{~d}$ - days; ${ }^{\mathrm{M}} \mathrm{Mo}$ - monoecious; ${ }^{6} \mathrm{Am}$ - andromonoecious 
than in control plants. Perfect flowers on andromonoecious plants treated with ethrel were recorded only 2 days earlier than control (Table 3).

Gibberellic acid delayed time of emergence of the first pistillate flower in monoecious plants for 2 days, and the first perfect flower in andromonoecious plants emerged with 1 day delay, compared to control (Table 5).

Byers et al. (1972) found that treating monoecious cucurbits with ethylene or compounds that promote ethylene synthesis causes earlier production of pistillate flowers, that is, promote feminization. They found that application of $\mathrm{GA}_{3}$ promotes masculinization in cucumber gynoecious plants, but not in melon gynoecious plants. The external application of ethrel in monoecious melon genotypes affected time of emergence and number of staminate and pistillate flowers. In andromonoecious melon genotypes this effect was reduced only for the emergence of both flower sex types and number of staminate flowers (Stankovic et al. 2001, Stankovic et al. 2005).

Ethrel delayed the emergence of the first staminate flower in monoecious plants for 13 days, in comparison to the control. A stronger effect was observed in andromonoecious plants, in which ethrel delayed the emergence of the first staminate flower for 19 days, compared to control. The strongest effect was recorded in cultivar Anannas, in which male flowers emerged 22 days later in the plants treated with ethrel, compared to the control (Table 3).

Gibberellic acid had a weak or neutral effect on the studied genotypes. The strongest positive effect was recorded in ED-3 monoecious cultivar plants sprayed with $\mathrm{GA}_{3}$, in which staminate flower was developed 3 days earlier, compared to the control plants (Table 5).

Stankovic et al. (2001) also found that ethrel affects melon sex expression and delays the flowering process. In their research, emergence of staminate flowers was delayed 25 to 30 days, compared to control. In their study ethrel was more effective in monoecious plants than in andromonoecious plants.

\section{Efeito da aplicação de reguladores de crescimento na expressão sexual em melão (Cucumis melo L.)}

Plants treated with ethrel, firstly had pistillate/perfect flowers, while the staminate flowers emerged 12.23 (Sesame) to 25.39 (Pobeditel) days later for monoecious genotypes, or 20.16 (A2-31b) to 23.67 (Chinese muskmelon) days later for andromonoecious genotypes (Table 3). Generally, ethrel was found more effective for andromonoecious varieties. Staminate flowers appeared two days earlier than perfect flowers in andromonoecious plants which were treated with gibberellic acid. Effect of gibberellic acid on trait "period from the emergence of the first staminate to the emergence of the first pistillate flower per plant" was not significant in monoecious plants (Table 5).

Summarizing, in this study, three plant growth regulators were used in eight monoecious and andromonoecious genotypes. Effects of hormones were observed in seven traits. Based on the results, it was found that ethrel affected: 1) the number of pistillate/perfect flowers per plant, 2) the number of staminate flowers per plant, 3) period from sowing to the emergence of the first pistillate/perfect flower, 4) period from sowing to the emergence of the first staminate flower, 5) period from sowing to full fruit ripening and 6) period from the emergence of the first pistillate to the emergence of the first staminate flower per plant. GA affected three characteristics: 1) the number of staminate flowers per plant 2) period from sowing to the emergence of the first pistillate/perfect flower, and 3) period from sowing to full fruit ripening.

Comparing monoecious to andromonoecious plants, the effect of Ethrel and $\mathrm{GA}_{3}$ differed for: 1) the number of pistillate flowers per plant, 2) the number of staminate flowers per plant, and 3) the number of fruits per plant.

\section{ACKNOWLEDGEMENTS}

This study was supported by the Project TR31059: "New approaches of vegetable breeding designed for use in sustainable growing systems based on biotechnological methods" of Ministry of Education, Science and Technological Development (Government of the Republic of Serbia).

\begin{abstract}
Resumo - Foram selecionadas sete características relacionadas ao florescimento e expressão do sexo no melão e, em seguida, observada a reação de dois reguladores de crescimento (Ethrel e ácido giberélico). Quatro genótipos de flores monóicas (Gergelim, ED-3, ED-4, Pobeditel) e quatro genótipos andromonóicos (Melão chinês, Anannas, Fiata, A2-3lb) foram ensaiados durante dois anos. Ethrel teve um efeito mais forte do que o ácido giberélico, aumentando o número de flores femininas/hermafrofitas por planta para 7,18 (40,61\%) e reduzindo o número de flores masculinas para 21,47 (17,98\%). Ethrel adiantou o aparecimento da primeira flor feminina/hermafrofita em 3,68 dias, e atrasou o aparecimento da primeira flor masculina em 16.07 dias. Como consequência, percebe-se que Ethrel prolonga o período entre o aparecimento da primeira flor fêmea/hermafrodita até a primeira flor masculina de 0,1 dia para 21,57 dias, sendo este o efeito mais forte (99,49\%).
\end{abstract}

Palavras-chave: Andromonóico, ethrel, flor, ácido giberélico, monóico. 


\section{REFERENCES}

Abdelmohsin ME and Pitrat M (2008) Pleiotropic effect of sex expression on fruit shape in melon. In Pitrat M (ed.). Proceedings of the $\mathbf{I X}^{\text {th }}$ EUCARPIA meeting on genetics and breeding of cucurbitaceae. INRA, Avignon, p. 551-555.

Aydinalp C (2010) Some important properties and classification of vertisols under Mediterranean climate. African Journal of Agricultural Research 5: 449-452.

Boualem A, Fergany M, Fernandez R, Troadec Ch, Martin A, Morin H, Sari MA, Collin F, Flowers JM, Pitrat M, Purugganan MD, Dogimont $\mathrm{C}$ and Bendahmane A (2008) A conserved mutation in an ethylene biosynthesis enzyme leads to andromonoecy in melons. Science 321: $836-838$.

Boualem A, Troadec Ch, Kovalski I, Sari MA, Perl-Treves R and Bendahmane A (2009) A conserved ethylene biosynthesis enzyme leads to andromonoecy in two Cucumis species. PLoS ONE 4: e6144

Brantley BB and Warren GF (1960) Sex expression and growth in muskmelon. Plant Physiology 35: 741-745.

Byers RE, Baker LR, Sell HM, Herner RC, Dilley DR (1972) Ethylene: a natural regulator of sex expression of Cucumis melo L. Proceedings of the National Academy of Sciences of the United States 69: 717-720.

FAO (2010) FAO Statistical Yearbook 2010 (FAOSTAT Data 2010). Available at $<\mathrm{http}$ ://faostat.fao.org > Accessed on March 28, 2012.

Fisher RA (1935) The design of experiments. Oliver and Boyd, London, $251 \mathrm{p}$.

Freeman DC, Harper KT and Charnov EL (1980) Sex change in plants: old and new observations and new hypotheses. Oecologia 47: 222-232.

Little HA, Papadopoulou E, Hammar SA and Grumet R (2007) The influence of ethylene perception on sex expression in melon (Cucumis melo L.) as assessed by expression of the mutant ethylene receptor, Atetr1-1, under the control of constitutive and floral targeted promoters. Sexual Plant Reproduction 20: 123-136.

Manzano S, Martinez C, Kraakman P and Jamilena M (2008) Use of ethylene production as a marker for the selection of gynoecy in melon (Cucumis melo). In Pitrat M (ed.) Proceedings of the IXth EUCARPIA meeting on genetics and breeding of cucurbitaceae. INRA, Avignon, p. 557-561.
Martin A, Troadec Ch, Boualem A, Rajab M, Fernandez R, Morin H, Pitrat M, Dogimont C and Bendahmane A (2009) A transposon-induced epigenetic change leads to sex determination in melon. Nature 461 : 1135-1139.

Noguera FJ, Capel J, Alvarez JI and Lozano R (2005) Development and mapping of a codominant SCAR marker linked to the andromonoecious gene of melon. Theoretical and Applied Genetics 110: 714-720.

Ouzounidou G, Papadopoulou P, Giannakoula A and Ilias I (2008) Plant growth regulators treatments modulate growth, physiology and quality characteristics of Cucumis melo L. plants. Pakistan Journal of Botany 40: 1185-1193.

Papadopoulou E, Little HA, Hammar SA and Grumet R (2005) Effect of modified endogenous ethylene production on sex expression, bisexual flower development and fruit production in melon (Cucumis melo L.). Sexual Plant Reproduction 18: 131-142.

Pitrat M (2008) Melon. In Prohens J and Nuez F (eds) Handbook of plant breeding: vegetable. Vol. I. Springer Science, New York, p. 283-316.

Stankovic L, Susic Z and Surlan-Momirovic G (2001) Muskmelon sex expression modified by ethrel. Contemporary agriculture 50: 269-272.

Stankovic L, Stevanovic D and Zdravkovic M (2005) Neki efekti Etrela na biljke iz familije cucurbitaceae. Journal of Scientific Agricultural Research 66: 81-88.

Thomas TD (2008) The effect of in vivo and in vitro applications of ethrel and $\mathrm{GA}_{3}$ on sex expression in bitter melon (Momordica charantia L.). Euphytica 164: 317-323.

Wang YH, Joobeur T, Dean RA and Staub JE (2007) Cucurbits. In Kole $\mathrm{C}$ (ed.) Genome mapping and molecular breeding in plants. Vol. 5 - Vegetables. Springer-Verlag, Berlin-Heidelberg, p. 315-329.

Whitaker TW (1931) Sex ratio and sex expression in the cultivated cucurbits. American Journal of Botany 18: 359-366

Yamasaki S, Fujii N and Takahashi H (2005) Hormonal regulation of sex expression in plants. Vitamins and Hormones 72: 79-110.

Yin T and Quinn JA (1995) Tests of a mechanistic model of one hormone regulating both sexes in Cucumis sativus. American Journal of Botany 82: 1537-154. 